\title{
PELOS CAMINHOS DA LOUVAÇÃO: A FESTA DE TODOS OS SANTOS NA COMUNIDADE DE JURUSSACA
}

\author{
Glayce de Fátima Fernandes da Silva ${ }^{1}$ \\ César Augusto Martins de Souza ${ }^{2}$
}

\begin{abstract}
RESUMO
Este artigo é um recorte da pesquisa empreendida na comunidade quilombola de Jurussaca, desenvolvida para a produção da Dissertação de Mestrado, apresentada ao Programa de PósGraduação em Linguagens e Saberes na Amazônia (PPLSA-UFPA). A comunidade de Jurussaca localiza-se no município de Tracuateua/PA, na Amazônia Oriental, suas terras são definidas por Silva (2014) como terras de preto e de índio, dada sua formação afro-indígena. Dentre as características da comunidade de Jurussaca destacam-se suas religiosidades populares, embora haja na comunidade diferentes manifestações religiosas, como as do catolicismo oficial, do catolicismo popular e da Assembleia de Deus. Desse modo, apresentamos neste artigo um estudo interpretativo da Festa de Todos os Santos (festa religiosa católica popular da comunidade), que teve origem a partir da promessa feita por antigos moradores, que pediram a intercessão de São Benedito (padroeiro da comunidade) e de Todos os Santos para que os homens do lugar, que haviam sido convocados à guerra, retornassem com vida, uma vez atendidos os moradores passaram a cumprir a promessa e, desde então, saem em procissão todos os anos, em louvor e agradecimento a essa e a outras graças alcançadas. A importância da Festa de Todos os Santos na identidade da comunidade se explicita na força e proporção do evento na comunidade. Para as populações negras rurais as festas religiosas têm importância intrínseca, pois a verdadeira cultura da festa evidencia o que mantém em cada um o sentido de pertencimento ao grupo (MOURA, 1998).
\end{abstract}

Palavras-chave: Religiosidade. Festa de Todos os Santos. Comunidade Quilombola de Jurussaca.

\begin{abstract}
This article is a section of the research engaged in the quilombola community of Jurussaca, developed to the production of a Master's degree dissertation presented to the Linguagens e Saberes na Amazônia Post-Graduation Program (PPLSA-UFPA). The Jurussaca community is located in the city of Tracuateua/PA, within the Eastern Amazon. Their lands are defined by Silva (2014) as black and Indian lands, due to its afro-indigenous formation. Among the features of the Jurussaca community, there are highlighted their popular religiosities, even though the community presents different religious manifestations, as the official Catholic religion, the popular Catholic religion, and other Christian religions. Thereby, this article presents an interpretative study of the Festa de Todos os Santos (a popular Catholic celebration of the community), which had its origin on a promise made by ancient dwellers that pleaded for the intercession of Saint Benedict (patron of the community) and for all the saints. They pleaded that the men of the place, which had been summoned to the war, could come back alive. Once this prayer was answered, the dwellers started to keep that promise and, since then, they join a procession every year, in honor and gratitude for this blessing and other blessings achieved by them. The importance of the Festa de Todos os Santos for the identity of the community is explicit in the strength and extent of the event in/for the community. To the black rural populations, the religious celebrations have an intrinsic importance, since the real culture of the celebration evokes what keeps, in each one, the sense of belonging to the group (MOURA, 1998).
\end{abstract}

Keywords: Religiosity. Festa de Todos os Santos. Jurussaca Quilombola Community.

\footnotetext{
1 Mestre em Linguagens e Saberes na Amazônia pela Universidade Federal do Pará (UFPA). E-mail: glaycesilv@gmail.com

${ }_{2}^{2}$ Professor da Universidade Federal do Pará (UFPA). Doutor em História pela Universidade Federal Fluminense (UFF). E-mail: cesar@ufpa.br.
} 
Recebido em: 09/05/2017

Aprovado em: 14/06/2017

\section{INTRODUÇÃO}

A comunidade quilombola de Jurussaca está localizada a $10 \mathrm{~km}$ da sede do município de Tracuateua e a $24 \mathrm{~km}$ do município de Bragança, na Amazônia Oriental. Situa-se na mesorregião do nordeste paraense e integra a microrregião Bragantina. A comunidade de Jurussaca não se diferencia das demais comunidades rurais da região do salgado paraense (campesina e ribeirinha), mas se insere entre as 523 comunidades reconhecidas e tituladas quilombolas no estado do Pará (GOMES, 2015).

Estudar a comunidade de Jurussaca, portanto, ajuda a compreendê-la como fruto do processo de formação da região bragantina, cuja influência está fortemente ligada às matrizes africanas e indígenas, dentre outras. Mas que se distingue das demais configurações de quilombos no território brasileiro, cujas variações resultam das diversas situações de acesso à terra: territorialidades específicas.

As territorialidades específicas desses grupos em contextos históricos e sociais distintos sugerem denominações variadas, como terras de preto, terras de santo, terras de santíssima (ALMEIDA, 2008), campo negro (GOMES, 1996), mocambos (SALLES, 2013), terras de preto e de índio (SILVA, 2014). Essas variações de nomeações evidenciam as singularidades da base territorial de cada grupo, bem como seus processos de formação.

Olhar para uma comunidade quilombola de forma mais específica requer abrir mão da visão geral sobre quilombolas e comunidades quilombolas no Brasil, na busca de compreender a particularidade da comunidade estudada. As histórias de formação das comunidades quilombolas são diversas e surgem de contextos sociais e históricos diferentes.

Comunidades quilombolas não são obrigatoriamente originárias de grupos de escravos fugidos, mas compõem grupos e/ou comunidades negras (urbanas ou rurais) que resistem (sobrevivem) socialmente a partir de seus modos de vida tradicionais. A comunidade de Jurussaca é uma comunidade afro-indígena e muito se assemelha a outras comunidades rurais formadas nas fronteiras abertas entre os estados do Pará e do Maranhão.

Neste artigo lançamos mão de um estudo interpretativo da Festa de Todos os Santos, um dos elementos de importante relevo na identidade da comunidade de Jurussaca. A Festa de Todos os Santos é uma festividade religiosa popular que vem sendo mantida na comunidade 
há várias gerações, representando a resistência do grupo por meio dessa tradição. É, pois, mediante estudos específicos, direcionados às tradições populares, que se tem conhecido parte da história e da cultura herdada da presença do negro na região Bragantina (CASTRO, 2006, p. 07).

Objetivamos assim, conhecer a origem da Festa de Todos os Santos, bem como interpretá-la como elemento de identidade da comunidade de Jurussaca. Para isso, alguns moradores da comunidade foram entrevistados, a quem chamaremos de Dona F, Dona M, Seu J e Seu V.

Em um primeiro momento, apresentamos a origem da Festa de Todos os Santos a partir das memórias de alguns moradores (de maior idade); em seguida situamos a Festa de Todos Santos com base em observações e participações empreendidas durante a festividade; por fim, oferecemos breves reflexões sobre a Festa de Todos Santos como elemento de afirmação de identidade do grupo.

\section{A ORIGEM DA FESTA DE TODOS OS SANTOS}

As populações remanescentes de quilombos dispõem de identidades que se constroem na coletividade do grupo e que, em contrapartida, se opõem às identidades que estão para além de suas fronteiras. A origem comum da comunidade de Jurussaca e as memórias coletivas de seus moradores representam importante elemento de resistência do grupo.

A origem comum, portanto, constitui para a comunidade um ponto que a diferencia de demais grupos. Conhecer a origem da Festa de Todos os Santos ajuda a compreender como a comunidade de Jurussaca criou uma tradição que não apenas traduz a comunidade enquanto quilombola, mas que representa a etnicidade que marca o contexto amazônico.

Acionar o passado recente da comunidade não poderia advir de melhor forma que por meio das palavras dos moradores mais antigos, os guardiões da memória: não temos nada melhor que a memória para significar que algo aconteceu, ocorreu, se passou antes que declarássemos nos lembrar dela (RICOEUR, 2007, p. 40). A memória, portanto, deve ser entendida não apenas como um instrumento capaz de armazenar informações mnemônicas; deve ser entendida, também, por sua capacidade de (re)significar as coisas e a si, uma vez que a memória é capaz de fazer a reconfiguração dos dados armazenados por meio do ato de rememorar.

A memória remete à posição de um real anterior. É a esse real anterior que a memória faz referência no tempo presente, é o que Ricoeur (2007) denomina como memória do 
passado. As memórias individuais estabelecem intersecções com a memória coletiva e se mantêm vivas por meio da rememoração.

É prática habitual entre os moradores da comunidade de Jurussaca a transmissão de suas memórias por meio da oralidade. Nessa repetição, alguns fatos ganham contornos diferentes, outros têm sua incidência gradativamente reduzida nas falas e outros, ainda, se tornam ausentes. A memória é isto, um trabalho contínuo e de caráter seletivo que está, igualmente, sujeito ao esquecimento. Memória, história e esquecimento são, na verdade, experiências necessárias na reconstrução de um passado (RICOEUR, 2007).

Aquilo que foi esquecido ou silenciado ao longo do tempo, na memória coletiva da comunidade, também está suscetível a uma leitura. Nesse sentido, Pollak (1989) afirma que as lembranças estão permeadas por zonas de sombra, silêncios, de não-ditos. As fronteiras desses silêncios e "não-ditos" com o esquecimento definitivo e o reprimido inconsciente não são evidentemente estanques e estão em perpétuo deslocamento (POLLAK, 1989, p. 6).

As memórias de um indivíduo ou um grupo não são apagadas por acaso ou por acidente. Há sempre motivos, conscientes ou inconscientes, que engendram esse efeito. As lembranças e os esquecimentos na memória coletiva constituem, igualmente, uma unidade identitária (RICOEUR, 2007). Com frequência, o passado que remete à escravidão negra no Brasil tende a passar pelo processo de esquecimento entre aqueles que carregam o estigma social de sua ancestralidade. Assim, ainda que a Festa de Todos os Santos (a festa religiosa de maior relevo na/da comunidade) apresente resquícios de influência africana, existe entre os moradores a afirmação da festividade como uma festa religiosa eminentemente católica.

Entende-se, segundo Pacheco (2010), que o campo religioso na Amazônia foi historicamente constituído como um espaço marcado por perseguição aos rituais afroindígenas pelos poderes eclesiásticos e civis. Contudo, "na contramão tornaram-se também territórios onde praticantes desses universos puderam resguardar e reafirmar suas religiosidades interligadas a divindades cultuadas por seus ancestrais" (PACHECO, 2010, p. 90).

A Festa de todos os Santos é entremeada por elementos que demonstram a resistência aos controles e intolerâncias impostas pelos poderes eclesiásticos e civis, em adaptações que refazem os espaços sagrados indígena e africano na festividade - o que é comum no contexto amazônico, onde as religiosidades passaram a inserir "outros repertórios e oráculos de matrizes culturais diversas, alguns para enlaçar empréstimos e influências recíprocas, outros para usar a arma dominante e não se deixar encapsular” (PACHECO, 2010, p. 90). 
A Festa de Todos os Santos teve início quando antigos moradores da comunidade fizeram uma promessa a São Benedito e a Todos os Santos para que se os homens da comunidade, que haviam sido convocados à guerra, voltassem com vida. Em agradecimento, os moradores fariam uma procissão com Todos os Santos da comunidade e com São Benedito (padroeiro do lugar). A prece foi atendida e os homens convocados à guerra retornaram com vida. Assim, a promessa se cumpriu e, desde então, alguns membros da comunidade retribuem aos Santos essa e outras graças alcançadas.

Os bisavôs de Dona $\mathrm{M}$ e de Dona $\mathrm{F}$ estiveram entre os primeiros promesseiros que deram origem à Festa de Todos os Santos. Dona M conta que foram as convocações para a Guerra do Paraguai $^{3}$ que deram origem à promessa a Todos os Santos e ao padroeiro:

Começou no tempo da Guerra do Paraguai. E eles que eram mais... mais antigos disseram... disseram que fizeram uma promessa com todos os santos. Se eles não fossem mais pra guerra como eles estavam indo, eles iam festejar isso, todos os santos. Aí começaram, aí quando parou, foi assim. (Dona M)

Além da Guerra do Paraguai, Dona M rememora a convocação para outra guerra, quando os homens eram pegos em qualquer lugar, em casa, nos caminhos, nas estradas, e eram levados à força. Ela conta que, da última vez, um de seus irmãos foi convocado junto a outros homens da comunidade. A promessa a Todos os Santos e a São Benedito então se repetiu, e mais uma vez a comunidade foi atendida. A guerra cessou e os homens regressaram com vida.

No início, a Festa de Todos os Santos apresentava características estruturais mais simples: "Aí, ia pelas casas dos irmãos e dos colegas que eram da promessa. Vamos dizer, era assim acho que era uma irmandadezinha. Aí faziam aquela festa, faziam manicuera, bebiam, e tinha a ladainha, aí tocavam tambor, dançavam, né? Coisa simples, né?”. (Dona F). Ela conta que a festividade acontecia apenas dentro das terras da comunidade em uma procissão pequena, ocasião em que se servia mingau de manicuera, entoava-se a ladainha, tocava-se tambor e dançava-se, o que difere da festividade contemporânea.

\footnotetext{
${ }^{3}$ A Guerra do Paraguai, (1864-1870) também conhecida por Guerra da Tríplice Aliança, aconteceu a partir da união de Brasil, Argentina e Uruguai contra o Paraguai. Embora a Inglaterra não tenha participado diretamente, foram seus mercadores, seus banqueiros e seus industriais que se beneficiaram com a Guerra do Paraguai. A invasão foi financiada, do começo ao fim, pelo Banco de Londres, a casa Baring Brothers e banco Rothschild, em empréstimos com juros leoninos que hipotecaram o destino dos países vencedores. A participação do Brasil contou com a convocação de muitos militares e civis, dentre estes estavam africanos escravizados no Brasil (e escravos libertos), além de índios. In: GALEANO, E. As Veias Abertas da América Latina. Tradução de Galeno de Freitas. 39ª ed. Rio de Janeiro: Paz e Terra, 2000. 307p. Título original: Las venas abiertas de America Latina. (Coleção Estudos Latino-Americanos, v.12).
} 
Há, na atualidade, uma nova configuração da Festa de Todos os Santos. Contudo, a memória sobre a origem da festividade é preservada pelos moradores, que encontram na devoção aos santos uma forma mantê-la viva. Os percursos da procissões hoje são maiores e a quantidade de santos (imagens de santos) aumentou na proporção do número de promesseiros.

Além da imagem de São Benedito, a família de Dona F herdou a promessa, e o mesmo ocorreu em outras famílias. Esta é uma característica que tem contribuído para a manutenção da festividade na comunidade. Em algumas casas, os mordomos não são os donos das promessas, pois as herdaram de seus familiares, que as herdaram de gerações passadas, junto às imagens dos santos. Dona $\mathrm{M}$, perguntada se em sua casa havia algum mordomo, ela responde:

Tem , era o meu marido. Ele morreu, ficou o filho... Olha, ele ficou no lugar do pai dele. É assim, ele ficou porque era o pai dele. E o menino já ficou no lugar dele. É, do pai passou pro João e do João já passou pro filho, que é esse daí. (Dona M)

Ela conta que não fez promessa para que o seu filho se tronasse mordomo. Segundo ela, a função foi herdada do seu pai que, por sua vez, também a recebeu do pai. A origem da promessa e a graça alcançada se perderam com o tempo, mas a manutenção da promessa, a fé e temor aos santos se mantêm. Dona $M$ atribui a manutenção da promessa à graça maior alcançada pela comunidade, que teria sido o fim da guerra: "Ele alcançou a graça que queria? Alcançou porque estamos tudo em paz, que nunca mais aconteceu isso né?” (Dona M).

Existem elos pessoais e familiares entre os mordomos e as promessas cumpridas, mas, além disso, há outro aspecto digno de nota quanto a fazer parte da Festa de Todos os Santos: o cumprimento de uma obrigação que é vista como coletiva, pois compartilhar dessa crença e manter a festividade ativa na comunidade reflete um sentimento de pertencimento ao local, à manutenção da tradição.

Desse modo, a manutenção da Festa de Todos os Santos na comunidade corrobora para a resistência de um elemento que muito representa a cultura da Amazônia: as religiões afro-indígenas. “As religiões afro-indígenas na Amazônia, desde o período colonial, sofreram vigilâncias da Coroa Portuguesa sob o olhar punitivo da Igreja" (PACHECO, 2010, p. 91). Por um longo tempo, as punições da igreja recaíram sobre essas populações socialmente marginalizadas que, em resposta, permaneciam unidas pela mesma crença que as legitimava enquanto grupo por torná-las diferentes dos demais. Desse modo, estes grupos,

munidos de suas crenças, apoiavam-se no imaginário religioso como reduto de valores culturais agredidos pelo colonizador. Desse modo a religião lhes servia de 
ponto de união, mas era também utilizada com vistas a sua divisão. (ACEVEDO MARIN, 1987, p. 63)

A Festa de Todos os Santos aderiu a elementos da religiosidade europeia (percebidos na devoção aos santos e na ladainha que é rezada em latim), mas conseguiu manter os elementos afro-indígenas, demostrando o quanto se manteve viva uma voz subterrânea, popular e sincrética "que representava a formação da voz nativa das Amazônias, em contato com o processo rápido e violento da conquista e colonização portuguesas” (MAUÉS, 1999, p. 88).

As religiosidades vivenciadas por um grupo social produzem marcas que o identificam e representam seus territórios. A Festa de Todos os Santos ocupa, entre as religiosidades da comunidade, o papel de representação de suas identidades. As memórias de origem da Festa de Todos os Santos estão atreladas às histórias da comunidade.

A tradição da festividade contribui para produzir a identidade territorial e fortalecer a memória coletiva da comunidade, pois "a tradição é um meio organizador da memória coletiva" (GIDDENS, 1997, p.82). A Festa de Todos os Santos representa algumas das identidades da comunidade de Jurussaca por ser mantida pelos moradores: “[...] a festa nossa aqui é tradição" (Seu V), o que a legitima como "um espaço privilegiado que mantém as diferenças das crenças e práticas tradicionais” (GIDDENS, 1997, p.101).

A fé que alguns moradores da comunidade de Jurussaca devotam aos santos e o modo de se relacionarem com os santos representa a maneira particular como eles veem e interagem com o mundo, colocando-os em um lugar diferente, no qual eles se projetam no mundo por meio da religiosidade popular e no qual se tornam protagonistas da própria história religiosa. "Essas crenças correspondem às práticas, que se traduzem em formas de culto, festas e rituais... os santos são objeto de culto e esse culto se expressa, frequentemente, por meio das festas" (MAUÉS, 2005, p. 268).

Durante a festividade, as relações sociais entre os moradores e as pessoas de fora da comunidade se invertem. No decorrer da Festa de Todos os Santos, a comunidade assume o centro dessas relações, negociando os valores e significados da festividade como elemento atrativo nas relações estabelecidas com os membros de outros grupos (comerciantes, fazendeiros, moradores de outras comunidades, pesquisadores etc.). É a comunidade que administra as relações com os outros.

A Festa de Todos os Santos se configura na comunidade de Jurussaca como uma forma simbólica espacial no processo de criação e manutenção de suas identidades étnica, racial, social, religiosa (CORRÊA, 2007). 
A tradição da Festa de Todos os Santos é mantida por sua repetição, ritualização e reinvenção, da origem aos dias atuais. Os eventos e as festas religiosas compõem o ciclo cultural da comunidade de Jurussaca, mas a Festa de Todos os Santos é para a comunidade a festividade de maior tradição, porque conflui para a manutenção das identidades do grupo e porque teria surgido antes de ser construída a primeira igreja da comunidade, antes mesmo da diocese de Bragança enviar os primeiros padres para celebrar missas ali.

Sendo assim, a Festa de Todos os Santos representa a resistência cultural e identitária que garante a manutenção de práticas da comunidade que tiveram origem no passado e que, apesar do contato com o catolicismo oficial, não foram pasteurizadas pela Igreja Católica. Essa festa de devoção aos santos está permeada por sentidos e significados que lhe são muito próprios, como as designações específicas para atribuições de papeis entre seus membros e as designações criadas para os dias início e encerramento da festividade (como Deixação, Buscação e Varrição). Suas especificidades dialogam com elementos que traduzem as realidades das populações amazônicas.

As identidades individuais dos moradores estão ligadas às identidades religiosas do grupo, à medida que cada morador/devoto de um santo cumpre com suas promessas aos santos durante a festividade, que é organizada e mantida pelos moradores em cumprimento da promessa inicial (que originou a festividade), hoje entremeada por diversas outras promessas feitas e outros milagres alcançados. "Em todas as sociedades, a manutenção da identidade pessoal, e sua conexão com identidades sociais mais amplas, é um requisito primordial de segurança ontológica" (GIDDENS, 1997, p. 100).

Desse modo, as representações que os moradores fazem da festividade inserem-na como elemento de identidade da comunidade, ainda que esta festividade não seja a única manifestação religiosa vivenciada por seus moradores e que a mesma, em diversos momentos, tenha sofrido influências. Entende-se assim que a Festa de Todos os Santos não foi totalmente refratária às tentativas de controle, "entretanto, precisamos reconhecer que essas tentativas estarão sujeitas a muitas rupturas, quer para o bem, quer para o mal” (GIDDENS, 1997, p. 220).

\section{IDENTIDADES NOS CAMINHOS DA LOUVAÇÃO: BUSCAÇÃO E DEIXAÇÃO DOS SANTOS}

Pelas curvas dos caminhos da comunidade de Jurussaca, das localidades e comunidades vizinhas, as procissões de Buscação e de Deixação dos Santos seguem 
anualmente, dividindo-se em dois principais momentos: no primeiro ocorre a busca dos santos, na procissão de Buscação; e no segundo os santos são devolvidos aos seus respectivos donos/devotos, na procissão de Deixação dos Santos.

A Festa de Todos os Santos apresenta uma estrutura organizacional bem definida e hierarquicamente estruturada. Ainda que se configure como uma religiosidade popular, apresenta características burocráticas com "delimitação explicita das áreas de competência e hierarquização regulamentada das funções... assim como a organização ordinária" (BOURDIEU, 2003, p. 59-60). As distribuições de papeis e suas respectivas atribuições estão expostas no quadro a seguir:

Quadro 1: Papeis assumidos pelos moradores na festividade

\begin{tabular}{|c|l|}
\hline Papeis & \multicolumn{1}{|c|}{ Atribuições } \\
\hline Herdeiros do santo & $\begin{array}{l}\text { Membros da família que herdou a imagem de São } \\
\text { Benedito (padroeiro da Festa de Todos os Santos). }\end{array}$ \\
\hline Rezadores & $\begin{array}{l}\text { São os senhores que puxam (cantam a primeira parte) da } \\
\text { ladainha, rezada em latim caboclo durante alguns } \\
\text { momentos da festividade. }\end{array}$ \\
\hline Tocadores & $\begin{array}{l}\text { Homens que tocam os instrumentos (tambor, reco-reco, } \\
\text { pandeiro e onça) que dão ritmo à ladainha. }\end{array}$ \\
\hline Juiz & $\begin{array}{l}\text { Responsável pela organização da festividade, desde a } \\
\text { comida distribuída aos que acompanham a procissão até a } \\
\text { festa dançante (som, segurança, bebida e bilheteria da } \\
\text { festa). Obrigatoriamente deve ser um mordomo. }\end{array}$ \\
\hline Mordomos & $\begin{array}{l}\text { Promesseiros que, em troca de alguma graça alcançada, } \\
\text { prestam ajuda financeira anual para a manutenção da } \\
\text { festa. São candidatos ao papel de juízes da festividade. }\end{array}$ \\
\hline Encarregado & $\begin{array}{l}\text { Responsável por definir os percursos que as procissões de } \\
\text { Buscação e Deixação seguirão durante a festividade. }\end{array}$ \\
\hline Carregadores de & $\begin{array}{l}\text { Homens que carregam as duas bandeiras estampadas com } \\
\text { a imagem do padroeiro durante a procissão e durante } \\
\text { todas as entoações da ladainha. }\end{array}$ \\
\hline bandeiras & $\begin{array}{l}\text { Pessoas que carregam as imagens dos santos envolvidas } \\
\text { em tolhas durante as procissões de Buscação e Deixação } \\
\text { dos Santos. }\end{array}$ \\
\hline Earregadores dos santos \\
Escrivão
\end{tabular}

A partir da observação das dinâmicas das estruturas burocráticas que compõem a Festa de Todos os Santos conforme a distribuição e atribuição de papeis apresentadas no quadro acima, é possível refletir que a burocracia serve mais como instrumento de manutenção da tradição que como instrumento de manutenção do poder. Isto porque, ao contrário do que 
acontece nas estruturas religiosas oficiais (institucionalizadas), as funções são assumidas apenas durante a festividade, não se estendendo ao cotidiano da comunidade.

A saída da procissão da Buscação dos Santos inicia a Festa de Todos os Santos no Jurussaca, que acontece em dois dias (oficiais ${ }^{4}$ ). Na Buscação, os carregadores dos santos e os demais participantes da festividade seguem em procissão conduzindo no colo as imagens dos santos e o Padroeiro 5 , envolvidas por panos ou toalhas. Os panos que envolvem os santos apresentam dois significados entre os moradores: o primeiro se refere à proteção da pureza dos santos, que são envolvidos por panos para que fiquem distantes dos pecados humanos; o segundo atribui à prática uma maior segurança na condução dos santos, devido aos longos percursos de procissão.

Durante a Buscação, os carregadores dos santos levam as imagens das casas de seus donos ao barracão de festas. Na Deixação, os santos são devolvidos do barracão de festas às casas de onde vieram. O mordomo de cada casa envia a imagem do santo de que é devoto (para o qual fez sua promessa) enrolada em uma toalha no dia da Buscação, recebendo-a de volta na Deixação dos Santos. O juiz da festividade não costuma acompanhar a procissão da Buscação, mas é comum que na Deixação o juiz do ano seguinte a acompanhe, sendo apresentado aos donos das casas visitadas e lhes estendendo um novo convite para a participação no ano posterior.

Os tocadores (de reco-reco, de tambor, de onça) se alternam ao tocar os instrumentos, mas mantêm o ritmo da ladainha, que é conduzida pelo som do tambor (por quem puxa a ladainha). Estes atores desempenham papel importante durante as visitações às casas dos

\footnotetext{
${ }^{4} \mathrm{Um}$ dia antes da abertura oficial da festividade, os rezadores, tocadores, encarregado, juiz atual da festividade e alguns moradores (que desempenharão o papel de carregadores de santo) vão à casa dos herdeiros do santo para conduzir o padroeiro ao barracão de festas (sede do clube de futebol da comunidade), onde a imagem pernoita e aguarda até o momento de saída da procissão de Buscação dos Santos (no dia seguinte). A saída da casa dos herdeiros do Santo é precedida pela Folia da Saída. Os rezadores cantam a Folia como uma espécie despedida feita aos moradores da casa. Esse cerimonial acontece também durante a esmolação de São Benedito na região Bragantina-PA (SILVA, 1997), assim como na esmolação de São Benedito na região de Óbidos-PA (VIEIRA, 2008). Sendo a folia uma reza cantada e instrumentalizada, dividida em duas partes: O canto introdutório e o canto a São Benedito. Após a Folia, as pessoas seguem da casa dos herdeiros do Santo para a sede/barracão da comunidade. Ao chegarem à sede, o Padroeiro e as imagens dos outros santos vindos da casa de Dona Fausta e Seu Jacó são colocados em um altar improvisado. Nesse momento os rezadores entoam a Folia da Chegada. Os santos permanecem ali até o dia seguinte. A quinta-feira é o primeiro dia da semana em que alguns moradores da comunidade saem de sua rotina comunitária para a organização da Festa de Todos os Santos. Além da quintafeira, os outros dias da semana que antecedem a festividade não aparentam ter o ritmo cotidiano alterado, exceto pela intensificação do trabalho nas roças. Muitos moradores desmontam suas roças de plantio de mandioca para a produção da farinha uma semana antes ou na mesma semana da festividade, com finalidade de ter dinheiro para gastar durante as festas dançantes.

5 Padroeiro é a maneira com os moradores chamam à imagem do santo São Benedito, esculpida em madeira, que é o padroeiro da Festa de Todos os Santos e da comunidade.
} 
mordomos. São eles que acompanham os rezadores e os carregadores de bandeira a cada casa visitada.

A procissão segue do barracão de festas em direção à localidade da Cebola, e de lá segue por várias comunidades, contornando do lado direito das terras da comunidade. Em seguida, passa em frente das Terras (comunidade de Quatro Bocas) até chegar a Santa Teresa (comunidade mais distante), de onde retorna (pelo lado esquerdo de suas terras) visitando mais casas, passando por outras comunidades e localidades até chegar ao Jurussaca.

Ao início da procissão e a cada casa visitada o encarregado da Festa de Todos os Santos é responsável por fazer a entrega da imagem a cada carregador de santo. O encarregado é também responsável por definir os trajetos que a procissão seguirá. O papel atual de encarregado da Festa de Todos os Santos é desempenhado por seu Vadeco e pode ser transferido a outra pessoa, à sua escolha, de forma definitiva ou provisória.

A transmissão de papeis, com suas respectivas atribuições, é uma das principais características da manutenção da tradição da Festa de Todos os Santos na comunidade de Jurussaca. Neste contexto, os rezadores são os atores de maior destaque nos rituais de visitação das casas, pois são eles que entoam a ladainha (atualmente, os rezadores são Seu Cristino e Seu Major). Seu Antônio é mais respeitado no papel de rezador, por sua maior experiência. Quando seu Antônio participa das visitas às casas, na Deixação ou na Buscação, é ele quem puxa ${ }^{6}$ a ladainha.

A condução do padroeiro a partir das casas de herdeiros do santo, que ritualiza a chamada Folia da Saída, não possui data fixa. Cabe à irmandade da Festa de Todos os Santos a definição da data para a Buscação, que ocorre geralmente uma ou duas semanas antes do dia de todos os santos. Desta forma, é definido apenas o dia da semana (sexta feira), sendo que a condução do padroeiro à sede acontece às quintas-feiras (pela parte da tarde). A irmandade se reúne no mês de agosto e decide a data conforme o calendário anual.

A flexibilização no calendário da Festa de Todos os Santos, assim como a decisão coletiva para a definição de uma data, permite identificar uma estrutura organizacional definida na qual a participação para decisões é horizontal. As irmandades presentes nas religiões de cunho popular (de influência africana e europeia), constituem-se como redes de parentesco entendidas para além das estruturas familiares e estruturas sociais comunitárias, atingindo a esfera religiosa.

\footnotetext{
${ }^{6}$ Puxar a ladainha é entoar a parte introdutória que, por sua vez será respondida pelo demais (tocadores e carregadores de bandeira).
} 
A cada casa de mordomo, entram apenas os rezadores, tocadores e o carregador do Padroeiro (geralmente uma mulher), apenas para deixá-lo na casa e pegá-lo ao final. Dentro das casas acontecem as ritualizações da visita: o santo protetor da casa fica em um altar improvisado ou oratório e as bandeiras são encostadas na parede, uma em cada lateral do altar, até que o Padroeiro esteja junto - momento em que os carregadores tomam novamente as bandeiras às mãos. Feito isso, o rezador inicia a instrumentalização da ladainha, entoando-a e para que outros respondam. O rezador e os carregadores de bandeira ficam à frente, os carregadores à lateral e o rezador ao centro. Ao fim da oração, todos deixam a casa. $\mathrm{O}$ encarregado entrega o Padroeiro a seu carregador e o santo protetor da casa a outro carregador.

As casas são preparadas para a acolhida do Padroeiro, onde são montados altares adornados com toalhas e flores. Os demais santos permanecem nas mãos dos carregadores de santo, que permanecem fora das casas. No altar são colocados o Padroeiro e as imagens dos santos da casa para que a parte introdutória da ladainha seja entoada, em latim caboclo. A preparação das casas demonstra a relação de respeito estabelecida entre os donos da casa e os santos.

Toda a oferta feita ao padroeiro, seja em dinheiro, flores ou bebidas, representa uma dádiva por alguma graça recebida. No entanto, a promessa que move os mordomos está relacionada a um dia assumirem o papel de juízes da festa. Algumas vezes, as promessas feitas se estendem para outros fins além desse, como oferecer almoço ou lanche a todos os que acompanham a procissão. Assim, a relação estabelecida entre os mordomos e os santos durante os ritos de visitas às casas acontece de duas formas: como dádiva (uma forma de agradecimento feito aos santos), ou cumprimento de promessa.

As ladainhas entoadas em latim compõem as tradições religiosas de devoção a São Benedito na região bragantina e outras regiões do estado. O culto a São Benedito expressa a influência afrodescendente na formação da comunidade, uma vez que permite encaixar, na delimitação metodológica dos gestos populares pela busca e alcance, de uma resistência ao cativeiro do catolicismo disciplinador. (SILVA, 1997).

Na Festa de Todos os Santos há designações próprias dadas aos participantes da festividade. Estas designações estão relacionadas às atribuições desempenhadas pelos moradores durante a festividade em uma organização específica: carregadores de santos, tocadores, herdeiros do santo, encarregado, escrivão, mordomos, juízes e rezadores. Nota-se que há uma estrutura construída para manutenção hierárquica entre os participantes da festividade. 
Os atores que desempenham os papeis centrais na Festa de Todos os Santos podem ser identificados considerando dois contextos: um contexto maior (da festividade) e um contexto menor (dos rituais da festividade). No contexto maior estão os herdeiros do santo e o juiz da festa - este por ser o responsável anual da mesma, aqueles por manterem na família e na comunidade a guarda do padroeiro.

No contexto menor estão os rezadores, responsáveis por conduzir todo o ritual de oração a cada casa visitada e no momento central da festividade: no segundo dia da Buscação, quando todos os santos são reunidos no altar, a fim de receberem as louvações de seus donos (mordomos) e devotos. Em ambos os momentos são os rezadores os encarregados da entoação da ladainha.

Esta organização hierárquica pode ser compreendida como uma representação da luta nos campos de poder. Esse poder está centrado no juiz, ao menos temporariamente, enquanto se encontra como o responsável pela festividade. No contexto ritualístico o poder é mantido pelo rezador. No entanto, o poder maior é exercido pela família dos herdeiros dos santos, cuja missão é zelar pela tradição da festividade.

Há, assim, a formação de um campo social, que segundo Bourdieu (2003), pode ser compreendido como um campo de forças que é imposto aos atores sociais dispostos nesse campo. A Festa de Todos os Santos ocupa um lugar privilegiado na comunidade, e a família herdeira do santo ocupa, igualmente, um lugar privilegiado, uma vez que há uma estrutura de relações sociais no espaço da comunidade, também estruturado, cujos limites são construídos e mantidos pelo grupo.

Após a repetição do ato de entrar e sair de várias casas ao longo do dia para a Buscação dos Santos, a procissão retorna à comunidade de Jurussaca. Ao final, as pessoas se organizam em meio ao campo de futebol, onde acontece uma espécie de encenação antes da entrada no barracão. Este momento se repete no segundo dia da Buscação, porém com a ritualização da passagem do santo (das mãos da família dos herdeiros do santo) para o juiz do ano vigente.

A manifestação das festas populares está associada a um ritual que impõe: Uma ordem de poderes que sente como incontroláveis, procura transcender a coerção ou a frustração de estruturas limitativas através de sua reorganização cerimonial, imagina outras práticas sociais, que às vezes chega a pôr em prática no tempo permissivo da celebração. (CANCLINI, 1983, p. 55)

De acordo com Canclini (1983) os rituais que marcam as festas populares representam uma ordem de poder, o que é percebido na Festa de Todos os Santos pela hierarquização. 
Assim, a ordem de poder se estabelece de forma quase incontrolável, transcendendo na festividade a coerção social a que a comunidade é submetida em outras esferas sociais (nãoreligiosas) e em outros momentos. "A lógica de relação simbólica impõe-se aos sujeitos como um sistema de regra absolutamente necessário em sua ordem" (BOURDIEU, 2003, p.25).

As atribuições de papeis assumidos por alguns moradores representam uma reprodução das estruturas maiores, marcadas por limitações, mas que durante a festividade se manifestam internas ao grupo (ainda que inconscientemente). "A festa sintetiza a totalidade da vida de cada comunidade, a sua organização econômica e suas estruturas culturais, as suas relações políticas e as propostas de mudança” (CANCLINI, 1983, p.55).

A partir da Festa de Todos os Santos é possível identificar uma teia de relações estabelecida entre a festividade e outras esferas da comunidade, a exemplo de sua organização econômica baseada na agricultura (em especial na produção de farinha). Em função da data da festividade, os moradores programam o tempo de produção da farinha de modo a coincidir com o período da Festa de Todos os Santos. O esforço se deve à possibilidade de investir (financeiramente) na festa, seja para pagar a entrada na festa dançante, seja para comprar roupas e sapatos novos (costume mantido entre os moradores), ou consumir bebidas e alimentos vendidos durante a festa dançante.

As festas dançantes que acontecem na sexta-feira e no sábado à noite, após a buscação dos santos, é fechada, ou seja, há cobrança para entrada. Contudo, todos os que acompanham a procissão recebem o ingresso (que lhes garante a entrada franca). Assim, o número de jovens durante a Buscação é mais expressivo que na Deixação, pois nesta última raramente o juiz organiza uma festa dançante.

Quanto às estruturas culturais, a Festa de Todos os Santos revela alguns costumes e crenças dos moradores, tal como o costume de oferecer um agrado ${ }^{7}$ a quem visita suas casas. $\mathrm{Na}$ festividade é praxe oferecer bebidas (cachaça para os homens e batida ${ }^{8}$ para as mulheres), café ou suco. Este hábito é comum entre os moradores da comunidade, como forma de recepcionar seus visitantes.

Esse comportamento constitui um indício do perfil do homem das comunidades rurais da Amazônia no que tange à forma de estabelecer contatos receptivos, exemplificando o que Giddens (2003) denomina como relacionamento de tipos mais tradicionais de laços sociais, que segundo ele depende de processos de confiança ativa:

\footnotetext{
${ }^{7}$ Agrado é o termo utilizado para fazer referência a doação de bebidas ou dinheiro aos que acompanham a procissão (rezadores, tocadores, buscadores e deixadores de santos).

${ }^{8}$ As batidas são bebidas preparadas com suco de fruta e cachaça (caju, maracujá, caju, bacuri e outras frutas).
} 
Depende de processos de confiança ativa - a abertura de si mesmo para o outro. Franqueza é a condição básica da intimidade. O relacionamento puro é intimamente democrático... se considerarmos o modo como um terapeuta vê um bom relacionamento. (GIDDENS, 2003, p.70-71)

A procissão da Buscação inicia com o padroeiro (imagem de São Benedito) e três imagens de santos que são conduzidos a partir da casa de seus herdeiros. Ao findar do dia, porém, são muitos os santos que pernoitam na sede de festas. Os santos dividem o mesmo espaço em que acontece a festa dançante de aparelhagem.

No momento em que os santos são colocados no altar improvisado, é possível identificar uma crença existente entre os participantes da festividade: a de que os santos precisam de luz, e que se esta luz não lhes for oferecida, a comunidade será de alguma forma castigada. Assim, as velas e as lâmpadas não podem ficar apagadas. Quando isso acontece, acredita-se que episódios desagradáveis, como brigas, podem transcorrer durante a festa dançante.

Sendo assim, "esses litigiosos relacionamentos põem no palco da luta cultural saberes e religiosidades de populações locais, contaminadas por outros contatos" (PACHECO, 2010, p. 104). Ainda a favor de benefícios e como forma de evitar possíveis castigos por parte dos santos, os moradores oferecem cachaça a eles, em uma espécie de negociação para que tenham uma festa bonita e abençoada. Esta característica expressa uma face das religiosidades das populações da Amazônia, que integram "crenças mistas ao associarem santos, caruanas, orixás, num mosaico de práticas culturais, festas e rituais sagrados” (PACHECO, 2010, p. 104).

As imagens dos santos permanecem neste espaço durante os dias da festividade, do primeiro dia de Buscação à Varrição ${ }^{9}$, o que é justificado como sendo a vontade dos próprios santos, "eles querem ficar aqui, porque a festa é deles, é pra eles", diz uma senhora carregadora de santos. A comunidade negocia com os santos e, ao mesmo tempo, estabelece com eles uma relação de temor, pois creem que estes são dotados de vontade e poder.

Na origem da Festa de Todos os Santos, a marujada acontecia dentro festividade. A princípio dançava-se a mazurca, o retumbão, o xote e o chorado, tocava-se tambor, reco-reco, pandeiro, onça, e a viola. Posteriormente, a marujada foi substituida pela festa dançante. Os santos permaneciam no mesmo espaço da festa dançante, e esta tradição que se manteve, porém não mais nas antigas barracas cobertas de palha contruídas anualmente.

\footnotetext{
${ }^{9}$ Varrição é o nome dado à festa dançante promovida na segunda-feira, com a finalidade de vender o que ficou de bebida e comida dos dias anteriores. No passado o dia da varrição era dedicado à limpeza de tudo o que foi deixado sujo no barracão de festas na festa da Buscação.
} 
As mudanças ocorridas na Festa de Todos o Santos apontam, por um lado, para a imposição de mudanças e, por outro, para a aderência de novos costumes, o que em certa medida permite a preservação de algumas de suas características. Desta forma,

\footnotetext{
quanto mais a tradição perde terreno, e quanto mais reconstitui-se a vida cotidiana em termos da interação dialética entre o local e o global, mais os indivíduos vêem-se forçados a negociar opções por estilos de vida em meio a uma série de possibilidades. (GIDDENS, 1997, p.5)
}

Segundo assinala Giddens (1997), as mudanças percebidas nas tradições estão atreladas aos contextos globais. Na Festa de Todos os Santos isso é sinalizado pela adoção da tecnologia no local. No entanto, a comunidade conseguiu estabelecer vínculos com aquilo que representa sua tradição ao manter a marujada, ainda que deslocada da festividade. As festas de aparelhagem adotadas como atração durante a Festa de Todos os Santos oferecem um repertório musical diferenciado, no qual predominam as exigências dos moradores, que optam pelo xote em diversos momentos.

A Buscação tem continuidade no segundo dia (sábado). Antes da saída da procissão, o juiz serve uma refeição feita de miúdos de boi. Desta vez, as casas visitadas são as existentes dentro das terras da comunidade, o que implica em um percurso menor de procissão, porém com mais casas para visitar e mais santos para carregar. Este é o dia em que predomina a presença das crianças, que desde pequenas participam da festividade e carregam os santos de casa em casa até completar o percurso da procissão. Na vida adulta as meninas manterão o papel de caregadoras dos santos, enquanto os meninos poderam assumir outras funções, tais como carregadores de bandeiras, tocadores e rezadores.

Assim como nos trabalhos com terra e nas relações de respeito impostas para com os mais velhos, as crianças da comunidade também recebem ensinamentos sobre as práticas religiosas, legitimando-os na participação direta em tais contextos. Durante estes contatos diretos, as crianças imitam e repetem os gestos e atos dos adultos, efetivando a tradição da Festa de Todos os Santos e sua continuidade de geração em geração.

Ao fim do segundo dia, a procissão chega ao centro da comunidade. O último lugar visitado é a igreja que fica à beira do campo de futebol, de onde trazem sua padroeira. Em frente ao barracão os herdeiros do santo esperam a chegada da procissão para ritualizar a passagem do santo das mãos dos herdeiros ao juiz. As pessoas que acompanham a procissão esperam no meio do campo; os carregadores de bandeira avançam em direção aos herdeiros do santo; lá, cruzam as bandeiras; trazem os herdeiros do santo em direção ao juiz; todos desenrolam as fitas dos santos; o padroeiro é passado de mãos; todos se ajoelham; retiram os 
chapéus; rezam em latim; levantam-se e seguem para o barracão; à frente, vão os carregadores de bandeiras que as cruzam na porta do barracão; a procissão inteira passa por baixo das bandeiras cruzadas. Lá dentro, os santos são mais uma vez reunidos no altar; os rezadores e tocadores entoam a introdução da ladainha.

Dentro do barracão os santos ganham seus lugares no altar, e então a louvação daquele momento se encerra. Todos os santos que foram buscados nos dias da Buscação ficam nesse altar. Aproximadamente às nove horas da noite todos retornam ao barracão para receber o anúncio do juiz que assumirá a festividade no ano seguinte.

Todos os mordomos devem estar presentes no barracão e aguardar até que seja revelado o nome do próximo juiz. Com velas nas mãos, eles acompanham os rezadores e tocadores na entoação da ladainha inteira. Após a entoação da ladainha, o nome completo de cada mordomo é lido. São mais de setenta mordomos, quase todos com o mesmo sobrenome (Araújo), todos eles com histórias de graças alcançadas, atendidas pelo padroeiro e por todos os santos.

A Festa de Todos os Santos não tem seu ciclo encerrado nesse dia. O domingo é dia de descanso da comunidade. Na segunda feira acontece a festa dançante chamada de varrição, que encerra a primeira parte da Festa de Todos os Santos. Dona F conta que a varrição iniciou para os fins de limpeza e organização do local da festa: “Quem varria, varria, quem lavava, lavava, mas era isso a varrição. Agora não! Tá tudo mudado" (Dona F).

No dia seguinte, todos os santos dos dois dias da Buscação são levados à igreja onde são arrumados no chão, atrás do altar, e lá permanecem até o dia da Deixação. Aproximadamente 15 dias depois, as pessoas que participam da festividade se dedicam à Deixação dos Santos, devolvendo os todos Santos recolhidos às casas de seus devotos (e donos). A Deixação também dura dois dias, e também nessa ocasião é entoada a introdução das ladainhas, a cada casa, após cada caminho, em cada comunidade e localidade visitada.

Os caminhos são os mesmos e os mesmos rituais se repetem, mas na Deixação as imagens dos santos retornam às casas de seus donos e promesseiros (mordomos). Novamente a procissão segue pelos caminhos e estradas de comunidades e localidade vizinhas durante o primeiro dia, enquanto no segundo percorre as terras da comunidade. Aqui também é costume a distribuição de comida, que é de responsabilidade do juiz da festa.

Algumas famílias que recebem a visita padroeiro e dos demais Santos providenciam algum agrado aos que acompanham a procissão: almoço (em virtude do cumprimento de alguma promessa por graça alcançada); café ou suco; uma pequena quantia em dinheiro; cachaça ou batida (estes consumidos por alguns durante a procissão). 
A ritualização de chegada e saída, antes e depois das procissões da Buscação e da Deixação, são os mesmos, mas desta vez a família dos herdeiros do santo não comparecem à sede. A família herdeira do santo aguardará o retorno do Padroeiro em sua casa um dia após o segundo dia de Deixação.

Para Moura (1998), as festas religiosas para os escravos negros representavam uma manifestação de resistência, pois a invocação de deuses e santos consistia em uma maneira muito particular de pedir proteção contra as opressões a que eram submetidos. Assim, os grupos de quilombos ou aquilombados (formados mesmo que de forma heterogênea) encontravam na aproximação com os deuses e santos a manutenção de suas forças. Festejar os santos significou - e ainda significa - uma forma de sobreviver, viver e resistir ao poder e à opressão imposta a esses grupos humanos.

A Festa de Todos os Santos, portanto, é uma representação de luta, herdada das gerações passadas e se mantém viva (apesar de suas reconfigurações), graças à manutenção de força e resistência dos moradores da comunidade. Segundo Moura (1998) as pessoas procuram a transcendência a partir das festas religiosas, nas quais os pequenos desafios do cotidiano são esquecidos, ou superados pela fé devotada aos santos. A Festa de Todos os Santos assume assim a função de um caleidoscópio pelo qual é possível vislumbrar diversos aspectos das sociabilidades do grupo (MOURA 1998). Por meio de uma festa religiosa é possível tecer sínteses da vida comunitária, pois esta

\footnotetext{
permite entrever as múltiplas relações que têm lugar numa micro sociedade e os valores que assim ela explicita: do parentesco ao meio ambiente, do calendário agrícola ao respeito aos mais velhos, da produção artesanal à história dos ancestrais, da liderança feminina ao conhecimento das plantas, das relações de afetividade aos valores humanos considerados fundamentais. Por esta razão, a festa, com seus ritos e símbolos, revela os costumes, os comportamentos, os gestos herdados e aponta ao mesmo tempo para as negociações simbólicas entre essas comunidades negras e os grupos com os quais interagem (MOURA, 1998, p. 14).
}

Em vista do que assinala Moura (1998), entende-se que a Festa de Todos os Santos, através de seus ritos e símbolos, deixa transparecer as identidades da comunidade, através dos comportamentos humanos, dos gestos herdados, repetidos e manifestados pelo grupo (que, em geral, tendem a ser mais espontâneos, ainda que em cenas repetitivas/ensaiadas da festividade). 


\section{CONCLUSÃO}

A partir das observações e participações feitas durante a Festa de Todos os Santos, protagonizada pelos moradores da comunidade de Jurussaca, interpretamos que a festividade se coloca como um espaço de negociações simbólicas entre a comunidade e os outros (pesquisadores e membros de outras comunidades), mas é, também, um espaço de negociações do próprio grupo.

O papel da Festa de Todos os Santos e seus de rituais ultrapassam a esfera da religiosidade e atingem outras esferas sociais, à medida que contribui para a reafirmação e transmissão de valores da comunidade, o que garante ao grupo a posição de poder em relação a outros grupos e, ainda, mantém autoridade imposta e/ou negociada que existe no interior do grupo. A importância da festividade na identidade da comunidade se explicita na força e proporção do evento na comunidade.

No jogo das territorialidades da comunidade de Jurussaca e tantas outras comunidades quilombolas, incide também o campo religioso, que na comunidade de Jurussaca é percebido no comportamento religioso local, desdobrado em quatro principais religiosidades: catolicismo oficial, catolicismo popular, pajelança cabocla e Assembleia de Deus.

Nesse limiar intrínseco ao campo religioso da comunidade é possível identificar tensões e forças; mais especificamente, é evidenciada a força que as manifestações e práticas religiosas populares exercem sobre as demais, o que pode ser interpretado como uma imposição e resistência da comunidade em prol de sua identidade.

Assim, há no campo religioso da comunidade de Jurussaca uma força maior exercida pelas religiosidades populares. Isto ocorre de tal modo que suas proporções ultrapassam as fronteiras da comunidade. Esta, ao propagar a festividade como elemento de representação de suas identidades, territorializa-se simbolicamente.

Ressaltamos que não tivemos a intenção de esgotar na pesquisa e neste artigo as interpretações sobre a Festa de Todos os Santos da comunidade de Jurussaca, sobretudo por não ser esse o objeto de estudo definido na Dissertação, que foi desenvolvida com enfoque nas questões de identidades e territorialidades da comunidade de Jurussaca.

\section{REFERÊNCIAS}

ACEVEDO MARIN, Rosa Elizabeth. Trabalho Escravo e Trabalho Feminino no Pará. In: Cadernos do Centro de Filosofia e Ciências Humanas da UFPA. Belém, $\mathrm{n}^{\mathrm{o}}$ 12, abril/jun.1987, pp. 53-84. 
ALMEIDA, Alfredo Wagner B. Terras de Quilombos, Terras Indígenas, "Babaçuais Livres", "Castanhais do Povo", Faxinais e Fundos de Pastos: Terras tradicionalmente ocupadas. 2 ed. Manaus: PGSCA-UFAM, 2008.

BOURDIEU, Pierre. Gênese e estrutura do campo religioso. In: BOURDIEU, Pierre. A Economia das Trocas Simbólicas. São Paulo: Perspectiva, 2003.

CASTRO, Edna. Escravos e Senhores de Bragança. Belém: NAEA, 2006.

CANCLINI, Néstor García. As Culturas Populares no Capitalismo. São Paulo: Brasiliense, 1983.

CORRÊA, Roberto Lobato. Formas Simbólicas e Espaço: Algumas considerações. Revista Geographia, v. 9, n. 17, p. 7-17, 2007.

GAlEANO, E. As Veias Abertas da América Latina. Tradução de Galeno de Freitas. 39 ed. Rio de Janeiro: Paz e Terra, 2000. Título original: Las venas abiertas de America Latina. (Coleção Estudos Latino-Americanos, v.12).

GIDDENS, Anthony. A Vida Em Uma Sociedade Pós-Tradicional. In: BECK, U.; GIDDENS, A.; LASH, S. Modernização Reflexiva: Política, tradição e estética na ordem social moderna. São Paulo: Ed. UNESP, 1997. pp. 73-134.

GOMES, Flávio. Mocambos e Quilombos: Uma história do campesinato negro no Brasil. São Paulo: Claro Enigma, 2015.

GOMES, F. S. Quilombos do Rio de Janeiro do Século XIX, In: REIS, J. J.; GOMES, F. S. (orgs.): Liberdade Por um Fio: História dos Quilombos no Brasil. São Paulo: Cia das Letras, 1996.

MAUÉS, Raymundo Heraldo. Uma Outra "Invenção" da Amazônia: Religiões, histórias, identidades. Belém: CEJUP, 1999.

O simbolismo e o boto na Amazônia: Religiosidade, religião, identidade. In: História Oral e Religiosidade (Comunicação Oral). Rio Branco: VIII Encontro Nacional de História Oral, 02 a 05 de maio, 2006.

Um Aspecto da Diversidade Cultural do Caboclo Amazônico: a religião. In: Estudos Avançados, 2005, pp 259-254.

MOURA, Glória. A força dos tambores: a festa nos quilombos contemporâneos. In: SHWARCZ, Lilia Moritz; REIS, Letícia Vidor de Souza (Org.). Negras Imagens: Ensaios sobre cultura e escravidão no Brasil. São Paulo: Ed. Universidade de São Paulo: Estaçao Ciência , 1998, pp. 55 - 80 .

PACHECO, Agenor Sarraf. Encantarias Afroindígenas na Amazônia Marajoara: Narrativas, práticas de cura e (in)tolerâncias religiosas. Belo Horizonte: Horizonte, ISSN: 2175-5841, v. 8, n. 17, abr. jun., p. 88-108, 2010. Disponível em: 
http://periodicos.pucminas.br/index.php/horizonte/article/viewFile/P.21755841.2010v8n17p8 8/2504. Acesso em 07 jan. 2017.

SALES, Vicente. Os Mocambeiros e Outros Ensaios. Belém: IAP, 2013.

SILVA, Dedival Brandão. Os Tambores da Esperança: Um estudo sobre cultura, religião, simbolismo e ritual na festa de São Benedito da cidade de Bragança. São Luís: Falangola, 1997.

SILVA, Jair Francisco Cecim. O Português Afro-Indígena de Jurussaca/PA: Revisitando a descrição do sistema pronominal pessoal da Comunidade a partir da textualidade. Tese (Doutorado em Filologia e Língua Portuguesa) - Faculdade de Filosofia, Letras e Ciências Humanas, Universidade de São Paulo. São Paulo: USP, 2014. 